\title{
JERZY KOSTORZ \\ Problematyka powołania do życia konsekrowanego w katechezie młodzieży szkół ponadgimnazjalnych
}

W listopadzie 2013 roku papież Franciszek ogłosił Rok Życia Konsekrowanego. Zapowiedział go na okres od pierwszej niedzieli Adwentu 2014 r. do 2 lutego 2016 r. Okazją do obchodów Roku Życia Konsekrowanego stała się 50 rocznica dekretu soborowego Perfectae Caritatis o przystosowanej do współczesności odnowie życia zakonnego ${ }^{1}$ oraz Konstytucji dogmatycznej o Kościele Lumen gentium, która w rozdziale VI mówi o zakonnikach ${ }^{2}$. Ojciec Święty Franciszek hasłem Roku Życia Konsekrowanego uczynił następujące słowa: „Ewangelia, proroctwo, nadzieja - życie konsekrowane w Kościele dzisiaj”3. W „Liście apostolskim do wszystkich osób konsekrowanych z okazji roku życia konsekrowanego"» papież Franciszek nawiązał do posynodalnej adhortacji Jana Pawła II Vita consecrata ${ }^{5}$. Zachęcił osoby konsekrowane do odkrywania wartości całkowitego poświęcenia się Bogu, wspominania i opowiadania wielkich dzieł Bo-

Jerzy K O S T O R Z, ks. dr hab., prof. nadz. UO, pracownik Katedry Katechetyki i Teologii Pastoralnej Wydziału Teologicznego Uniwersytetu Opolskiego w Opolu, e-mail: jkostorz@uni.opole.pl

\footnotetext{
${ }^{1}$ Sobór Watykański II: Dekret o przystosowanej do współczesności odnowie życia zakonnego Perfectae caritatis. W: Sobów Watykański II. Konstytucje. Dekrety. Deklaracje. Pallotinum. Poznań $2002 \mathrm{nr} 1-25$.

${ }^{2}$ Sobór Watykański II: Konstytucja dogmatyczna o Kościele Lumen gentium. w: Sobór Watykański II: Konstytucje. Dekrety. Deklaracje, dz. cyt. nr 43-47.

${ }^{3}$ A. Gu rg a: Komunikat na rozpoczęcie Roku Życia Konsekrowanego (16 listopada 2014). www.jasnagora.com/wydarzenie-8986 [dostęp: 11.09.2015].

${ }^{4} \mathrm{Fr}$ a n c i s z e k: List apostolski Papieża Franciszka do zakonnic i zakonników na rozpoczęcie Roku Życia Konsekrowanego Świadkowie radości. (21 listopada 2014). http://w2.vatican.va/ content/francesco/pl/apost letters/documents/papa-francesco lettera-ap 20141121 letteraconsacrati.html [dostęp: 15.09.2015].

${ }^{5} \mathrm{~J}$ a n P a w e 1 I I: Posynodalna adhortacja apostolska o życiu konsekrowanym i jego misji w Kościele i w świecie Vita consecrata (25 maja 1996) [dalej: VC].
} 
żych, które dokonały się w ich życiu, rozwijania swojego powołania, pokonywania własnych słabości i grzeszności oraz ukazywania światu świętości i żywotności, która sprawia, że konsekrowani sa »żywymi ikonami Boga« po trzykroć Świętego ${ }^{6}$. Rok Życia Konsekrowanego jest doskonałą okazją do odkrywania przez wiernych świeckich i ludzi dobrej woli wartości całkowitego poświęcenia się Bogu, którego świadkami są osoby konsekrowane. Sprzyja też poznawaniu życia i specyfiki powołania osób konsekrowanych. Skłania do większej modlitwy za osoby powołane do życia konsekrowanego ${ }^{7}$. W naturalny sposób Rok Życia Konsekrowanego przenika do szkolnej i parafialnej katechezy. Mocno łączy się z tematyką powołania, która obecna jest w podstawie programowej, programach i podręcznikach katechetycznych.

Bez wątpienia problematyka powołania do życia konsekrowanego należy do kluczowych tematów w katechezie młodzieży szkół ponadgimnazjalnych. Na tym etapie katechizacji młody człowiek dokonuje wyborów dalszej drogi życiowej i decyduje o własnym losie. Po ukończeniu nauki w liceum lub technikum wybiera kierunek studiów lub podejmuje pracę. Niekiedy też łączy naukę z pracą. Po ukończeniu szkoły zawodowej uczeń może podjąć dalszą naukę w liceum lub technikum na podbudowie szkoły zawodowej lub podjąć pracę. Wyborom tym towarzyszy dążenie do osiągnięcia szczęścia osobistego np. w rodzinie $\mathrm{i}$ w relacjach przyjacielskich. Jednocześnie widać wyraźnie tendencje do nadmiernej koncentracji na sobie i zdrowym stylu życia oraz dążenie do życia w luksusie, posiadania elektronicznych gadżetów, konsumowania luksusowych dóbr materialnych, podnoszenia swojego statusu społecznego, przesadnego dbania o wygląd zewnętrzny oraz inwestowania w siebie - w kosmetyki, akcesoria, ubrania. $\mathrm{W}$ ten sposób młodzi ludzie dowartościowują siebie, podnoszą własną atrakcyjność, dostarczają sobie poczucia wyższości, a przez to stają się zapatrzeni w siebie. Jednocześnie odsuwają decyzję o założeniu rodziny lub wyborze innej drogi życiowej. ${ }^{8}$ Mówiąc o powołaniu do życia konsekrowanego w katechezie młodzieży ponadgimnazjalnej mówimy zatem o tym, co często wydaje się niemodne, mało atrakcyjne i odległe dla młodego człowieka. Próbujemy powiązać problematykę powszechnego powołania do świętości z wyborem szczególnej drogi życiowej, szczególnej, bo związanej z poświęceniem się Bogu poprzez konsekrację zakonną i zobowiązanie do życia radami, czyli naśladowanie Chrystusa czystego, ubogiego i posłusznego ${ }^{9}$.

\footnotetext{
${ }^{6}$ Cyt za: K. G u r g a: Komunikat na rozpoczęcie Roku Życia Konsekrowanego, dz. cyt. s. 2.

${ }^{7}$ Tamże.

${ }^{8}$ Zob. o tym np. w: A. R a k i t i n a: Dlaczego współczesna młodzież nie spieszy się z dorastaniem? Czytaj dalej: http://pl.sputniknews.com/polish.ruvr.ru/2014_05_02/Dlaczego-wspol czesna-mlodziez-nie-spieszy-sie-z-dorastaniem-4336/ [dostęp: 16.09.2015].

${ }^{9}$ Por. VC 12.
} 
Z uwagi na znaczenie katechetyczne problematyki powołania do życia konsekrowanego, warto nad nią podjąć refleksję i najpierw ukazać czy i w jaki sposób pojawia się ona w podstawie programowej katechezy ${ }^{10}$ i programach nauczania religii w liceum, technikum i w szkole zawodowej ${ }^{11}$. W wyżej wymienionych materiałach katechetycznych możemy znaleźć zapis celów, zadań, treści i sposobów realizacji założeń, które odnoszą się do różnych obszarów życia człowieka. Powstaje pytanie na ile obecna jest tam tematyka powołania życiowego i tej szczególnej formy jaką jest życie konsekrowane? Poszukajmy zatem na to pytanie odpowiedzi. Opisując problematykę powołania do życia konsekrowanego, zwrócimy uwagę na cele, treści i zadania bezpośrednio i pośrednio związane z powołaniem i życiem konsekrowanym. Zaakcentujemy problem kształtowania w uczniach umiejętności dokonywania właściwych wyborów dalszej drogi życiowej oraz wskażemy na potrzebę zmian programowych. Najpierw jednak krótko opiszemy istotę powołania do życia konsekrowanego. Pozwoli uniknąć to niejasności i wieloznaczności.

\section{Istota powolania do życia konsekrowanego}

Pojęcie „powołanie do życia konsekrowanego” na ogół w mowie potocznej rozumiane jest dość wąsko. Odnosi się je głównie do sióstr zakonnych. Sporadycznie wymienia się również braci zakonnych i kapłanów, którzy przynależą do zgromadzeń zakonnych. To nie wyczerpuje jednak wszystkich osób, do których pojęcie „życie konsekrowane” ma zastosowanie. Mówiąc o powołaniu do życia konsekrowanego mamy też na uwadze świeckie osoby konsekrowane. Po Soborze Watykańskim II ta forma życia zaczęła rozwijać się w Kościele katolickim. Nie tylko kobiety, ale również mężczyźni odkrywają powołanie do życia konsekrowanego w świecie. Jan Paweł II w adhortacji Vita consecrata wymienił następujące formy życia konsekrowanego podejmowanego tak przez kobiety, jak i przez mężczyzn: instytuty zakonne oddane całkowicie kontemplacji, instytuty

\footnotetext{
${ }^{10}$ Konferencja Episkopatu Polski: Podstawa programowa katechezy Kościoła katolickiego w Polsce. Kraków 2010 [dalej: PPK].

${ }^{11}$ Komisja Wychowania Katolickiego Konferencji Episkopatu Polski: Świadek Chrystusa. Katecheza świadectwa wiary. Program nauczania religii dla liceum nr AZ-4-01/10. W: Komisja Wychowania Katolickiego Konferencji Episkopatu Polski: Program nauczania religii rzymskokatolickiej w przedszkolach i szkołach, Kraków 2010 s. 139-169 (dalej: PNR Liceum); Komisja Wychowania Katolickiego Konferencji Episkopatu Polski: Świadek Chrystusa. Katecheza świadectwa wiary. Program nauczania religii dla technikum nr AZ-6-01/10. W: Komisja Wychowania Katolickiego Konferencji Episkopatu Polski: Program nauczania religii rzymskokatolickiej w przedszkolach i szkołach. dz. cyt. s. 171-206 (dalej: PNR Technikum); Komisja Wychowania Katolickiego Konferencji Episkopatu Polski: Swiadek Chrystusa. Katecheza świadectwa wiary. Program nauczania religii dla szkoły zawodowej nr AZ-5-01/10. W: Komisja Wychowania Katolickiego Konferencji Episkopatu Polski: Program nauczania religii rzymskokatolickiej w przedszkolach i szkołach. dz. cyt. s. 207-233 [dalej: PNR Szkoła zawodowa].
} 
zakonne oddane dziełom apostolskim (tzw. czynne), instytuty świeckie, stowarzyszenia życia apostolskiego oraz stan dziewic, pustelników i wdów poświęconych $\mathrm{Bogu}^{12}$. Ich cechą charakterystyczną jest stałość poświęcenia się Bogu i Kościołowi.

W przyjętym w teologii katolickiej rozumieniu powołania do życia konsekrowanego akcentuje się naśladowanie Chrystusa na drodze rad ewangelicznych: czystości, ubóstwa i posłuszeństwa ${ }^{13}$. Podkreśla się przy tym, że wszyscy wierni są wezwani do naśladowania Chrystusa czystego, ubogiego i posłusznego. Zaznacza się jednak, że osoby konsekrowane zostały powołane do szczególnej zażyłości z Jezusem i całkowitego oddania Mu siebie w sposób „niepodzielny", w celu uwielbienia Boga, budowania Kościoła i zbawienia świata ${ }^{14}$. Powołanie do życia konsekrowanego stanowi najbardziej radykalną formę życia Ewangelią i naśladowania Chrystusa ${ }^{15}$. Dlatego mówiąc o powołaniu do życia konsekrowanego, teologowie akcentują jego szczególny charakter ${ }^{16}$. Powołanie do życia konsekrowanego jest cennym darem i zadaniem. Każda osoba powołana do tej formy życia zostaje umocniona Duchem Świętym ${ }^{17}$. Zgodnie z przepisami danego instytutu lub zgromadzenia ma ona naśladować Chrystusa czystego, ubogiego, posłusznego, świadczyć o prymacie Boga nad sprawami doczesnymi oraz służyć ludziom na wzór Jezusa Chrystusa ${ }^{18}$.

Osoby konsekrowane składają publicznie - wobec przedstawicieli Kościoła - tzw. profesję, czyli śluby, zobowiązujące do zachowania rad ewangelicznych, których zachowanie pomaga $\mathrm{w}$ dążeniu do doskonałej miłości i służby na rzecz Królestwa Bożego ${ }^{19}$. Zachowując ślub czystości, osoby konsekrowane żyją we wstrzemięźliwości ${ }^{20}$. Nie tylko zachowują celibat i dobrowolnie rezygnują z małżeństwa i życia rodzinnego, ale także wybierają Chrystusa jako jedyną miłość ${ }^{21}$. Wypełniając ślub ubóstwa osoby konsekrowane naśladują Chrystusa ubogiego i pracowitego oraz używają i dysponują dobrami materialnymi w zależności

${ }^{12}$ VC 5-13.

${ }^{13}$ Zob. np. I. M i e r z w a: Życie konsekrowane. W: Stownik teologiczny. Red. A. Z u b e r b i e r. Katowice 1998 s. 697-698; Z. P o d l e j s k i: Życie konsekrowane w tajemnicy Kościoła. Kraków 2015; B. Z u b e r t: Konsekrowane życie. W: Encyklopedia katolicka. T. 9. Red. A. S z o s te k, B. M i g u t, R. S a w a (i in.). Lublin 2002 kol. 677-678.

${ }^{14} \mathrm{VC} 17-18$.

${ }^{15}$ B. Z u b e r t: Konsekrowane życie, dz. cyt. kol. 677-678.

${ }^{16}$ Zob. np. B. G i e m z a: Apostolski wymiar życia konsekrowanego w nauczaniu Jana Pawła II. Studium teologicznopastoralne. Wrocław 2012; J. G o ł ę b i e w s k i: Dar życia konsekrowanego: rozważania w świetle Adhortacji Vita consecrata. Warszawa 1998.

${ }^{17} \mathrm{VC} 19$

${ }^{18}$ VC 19. 25

${ }^{19}$ Tamże 20-22; por. T. P a s z k o w s k a: Konsekracja. W: Leksykon duchowości katolickiej. Red. M. C h mi e le w s k i. Lublin - Kraków 2002 s. 430-431.

${ }^{20}$ Tamże.

${ }^{21}$ Tamże. 
od zgody przełożonych ${ }^{22}$. To pomaga im odrywać się od przywiązania do rzeczy materialnych, kierować uwagę na dobra duchowe i potrzeby innych ludzi, a przez to odrywać się od przywiązania do rzeczy materialnych i zdobywać wolność wewnętrzną. Z kolei ślub posłuszeństwa zobowiązuje osoby konsekrowane do podporządkowania własnej woli prawowitym przełożonym, a przez to do włączenia się w realizację planów Boga na wzór Chrystusa pełniącego zawsze wolę $\mathrm{Ojca}^{23}$. Powołanie do życia konsekrowanego jest więc znakiem, który zapowiada Królestwo Boże i niebieską chwałę ${ }^{24}$. Do jego istoty należy szczególna łączność osób konsekrowanych z Kościołem i dbałość o zbawienie świata ${ }^{25}$. Takie, choć z uwagi na ramy niniejszego opracowania, ukazane w sposób bardzo ogólny, rozumienie istoty życia konsekrowanego stanowi punkt odniesienia w analizach podstawy programowej katechezy i programów nauczania religii.

\section{Tematyka powolania do życia konsekrowanego w podstawie programowej katechezy}

W obowiązującym od 2010 r. znowelizowanym tekście „Podstawy programowej katechezy Kościoła katolickiego w Polsce” dla szkół ponadgimnazjalnych ${ }^{26}$ możemy znaleźć cele, zadania i treści nauczania religii na temat powołania i życia konsekrowanego. Zaplanowane w podstawie programowej katechezy zagadnienia, w wielu miejscach, pośrednio, odnoszą się do powołania do życia konsekrowanego. $\mathrm{W}$ treściach programowych katechezy zwraca się uwagę na charakterystyczne cechy obrazu Chrystusa w poszczególnych Ewangeliach ${ }^{27}$. Są one istotne w kontekście naśladowania Chrystusa czystego, ubogiego i posłusznego. Obok tego obecne są takie treści, jak: wybrane drogi powołania chrześcijańskiego, relacje pomiędzy cnotami Boskimi a cnotami kardynalnymi, Misterium Kościoła, zgromadzenia zakonne w Kościele partykularnym, zasadnicze tezy nauczania Soboru Watykańskiego II i najważniejsze tezy nauczania papieża Jana Pawła II ${ }^{28}$.

Za istotne uznać należy treści, które bezpośrednio wiążą się z powołaniem i życiem konsekrowanym. W podstawie programowej katechezy wiele uwagi poświęca się znaczeniu ascezy w życiu chrześcijanina oraz postawie służby. Uczeń winien odkrywać, zarówno wartość ascezy, jak i służby ${ }^{29}$. Proponowane treści wskazują na sens ofiarowania siebie bliźnim i podejmowania trudu składa-

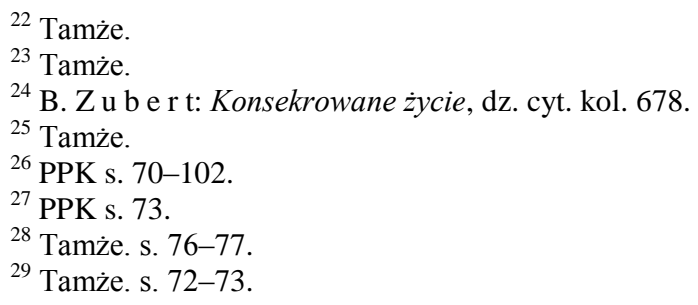


nia świadectwa wiary. Osoba Chrystusa jest tu ukazywana jako wzór godny naśladowania. Podobne spostrzeżenie nasuwa się, gdy czytamy o odkrywaniu powołania chrześcijańskiego ${ }^{30}$.

Szereg treści, istotnych dla problematyki powołania do życia konsekrowanego, możemy dostrzec w założeniach formacji moralnej, wychowania do modlitwy i wychowania do życia wspólnotowego. W podstawie programowej katechezy dla szkół ponadgimnazjalnych zakłada się doprowadzenie do odkrycia przez ucznia godności człowieka i powołania, którym obdarzyt go Bóg; prowadzenie do odkrycia wtasnego powołania życiowego; przygotowanie do podejmowania samodzielnych decyzji w oparciu o motywację chrześcijańska, wyptywajaca z faktu przyjęcia chrztu i bierzmowania; integrowanie orędzia chrześcijańskiego z ludzkim doświadczeniem codzienności; ukazanie życia chrześcijańskiego jako drogi ku doskonałości (świętości) ${ }^{31}$. Realizacja tych zadań jest ważna dla problematyki powołania do życia konsekrowanego. Pozwala uczniom poznać prawdę o sobie, własnej godności i wolności osoby ${ }^{32}$ oraz odczytywać człowieczeństwo jako dar od Boga i jako zadanie, na którym bazuje, właściwie realizowane, powołanie do życia konsekrowanego. Katechizowany ma oceniać różne przypadki zachowań moralnych. Podczas zajęć katechetycznych katechizowani poznają i analizują historie młodych osób, którzy wybierają wartości wyższe, rezygnują z dóbr materialnych i odpowiadają na Boże wezwanie do życia radami ewangelicznymi. Uczniowie dokonują też oceny zachowań, będących wyrazem konsumpcjonizmu i negacji Boga, jako najwyższej wartości. Prawidłowo podejmowane zagadnienia pomagają w lepszym zrozumieniu wartości życia jako daru od Boga i w odkryciu powołania do życia wiecznego. Dobrze więc, że w podstawie programowej katechezy mamy szereg propozycji ukazywania znaczenia życia w duchu Ewangelii i postępowania zgodnie z Dekalogiem. Ich właściwe zrozumienie i powiązanie z problematyką powołania od życia konsekrowanego wymaga wykorzystania metod poszukujących i problemowych ${ }^{33}$. Aktywny, oparty na dialogu i wzbogacony o modlitwę, udział młodzieży w szkolnej katechezie pobudza do refleksji nad własnym życiem. Może pomóc we właściwym rozeznaniu osobistego powołania ${ }^{34}$. Szkoda jednak, że w podstawie programowej katechezy pominięto założenia, które bezpośrednio odnoszą się do kształtowania postaw młodzieży wobec osób konsekrowanych i tej formy życia w Kościele. To wzmocniłoby oddziaływanie wychowawcze katechezy w zakresie rozeznawania powołania życiowego i zrozumienia sensu życia konsekrowanego we współczesnym świecie.

\footnotetext{
${ }^{30}$ Tamże.

31 Tamże, s. 75.

${ }^{32}$ Tamże.

33 Tamże, s. 79.

34 Tamże.
} 


\section{Tematyka powolania do życia konsekrowanego w programach nauczania religii}

Programy nauczania religii $\mathrm{w}$ szkołach ponadgimnazjalnych (w liceum ${ }^{35}$, technikum $^{36}$ i w szkole zawodowej ${ }^{37}$ ) zawierają zgodne z podstawą programową katechezy opisy celów, zadań i treści. Widzimy w nich rozpisanie na cykl trzyletni (w liceum), czteroletni (w technikum) i dwuletni (szkoła zawodowa) wytycznych $\mathrm{z}$ podstawy programowej katechezy. W wymienionych programach nauczania religii treści koncentrują się wokół wiary w Jezusa Chrystusa. Tematyka życia konsekrowanego występuje przede wszystkim w III klasie liceum ${ }^{38}$, IV klasie technikum ${ }^{39}$ i II klasie szkoły zawodowej ${ }^{40}$. Dostrzegamy tam tematy o powołaniu życiowym i chrześcijańskim powołaniu do świętości. Problematyka (...) powotania życiowego, gdy młodzież kończy ważny etap swego życia i staje przed wyborem dalszej drogi życiowej, jest szczególnie [- jak czytamy w programach nauczania religii - J.K.] interesujaca (...) i aktualna ze względu na pewien kryzys rodziny i zagrożenia życia ${ }^{41}$. Omawianie tematów związanych z powołaniem życiowym człowieka pozwala ukazać młodzieży sens życia realizowanego w oparciu o miłość, która objawiła się w Jezusie Chrystusie ${ }^{42}$. Dobrze też, że $\mathrm{w}$ powiązaniu $\mathrm{z}$ tymi zagadnieniami $\mathrm{w}$ programach nauczania religii $\mathrm{w}$ liceum, technikum i szkole zawodowej umieszczono treści związane $\mathrm{z}$ osobami powołanymi, o których dowiadujemy się na kartach Pisma Świętego ${ }^{43}$. To wzmacnia oddziaływanie wychowawcze i pozwala zrozumieć rozmaitość powołań w Kościele. Przyczynia się do pogłębienia wiedzy na temat powołania kapłańskiego, zakonnego, misyjnego i do życia konsekrowanego w świecie ${ }^{44}$. Cenne wydaje się też ukazanie Maryi jako osoby powołanej przez Boga ${ }^{45}$.

Powyższe treści związane z powołaniem do życia konsekrowanego trafnie zostały uzupełnione o modlitwę o odczytanie własnego powołania ${ }^{46}$. To zagadnienie pomaga w kształtowaniu zdolności rozeznawania powołania do życia konsekrowanego. Sama bowiem znajomość różnych dróg powołania chrześcijańskiego nie jest wystarczająca. Dla problematyki powołania do życia konsekrowanego ważny jest opis życia kapłańskiego, zakonnego, misyjnego, konsekrowane-

\footnotetext{
${ }^{35}$ PNR Liceum s. 139-169.

${ }^{36}$ PNR Technikum s. 171-206

${ }^{37}$ PNR Szkoła zawodowa s. 207-233.

${ }^{38}$ PNR Liceum, s. 163.

${ }^{39}$ PNR Technikum, s. 200.

${ }^{40}$ PNR Szkoła zawodowa, s. 218.

${ }^{41}$ PNR Liceum, s. 162; PNR Technikum, s. 199; Szkoła zawodowa, s. 217.

${ }^{42}$ Tamże.

${ }^{43}$ PNR Liceum, s. 163; PNR Technikum, s. 200; Szkoła zawodowa, s. 218.

${ }^{44}$ Tamże.

${ }^{45}$ Tamże.

${ }^{46}$ Tamże.
} 
go w świecie, jako służby Bogu i człowiekowi ${ }^{47}$. Nawiązując do tych zagadnień, można bowiem zwrócić uwagę młodzieży na czystość, celibat i dziewictwo oraz odpowiedzialność za życie zgodne $\mathrm{z}$ ewangelicznymi wartościami ${ }^{48}$. Tego rodzaju działania w liceum, technikum i w szkole zawodowej należy wzbogacić o pogtębianie motywacji do pracy nad sobą ${ }^{49}$.

Cenne wydają się tematy związane z macierzyństwem i ojcostwem oraz wychowaniem dzieci. Osoby konsekrowane powołane są bowiem do realizacji macierzyństwa i ojcostwa duchowego. W pracy apostolskiej często wypełniają zadania wychowawcze wobec dzieci i młodzieży. Stąd też pogłębienie rozumienia wartości macierzyństwa i ojcostwa duchowego ma duże znaczenie w realizacji powołania do życia konsekrowanego. Omawianie tych zagadnień ma pomagać młodzieży z liceum, technikum i szkoły zawodowej, z jednej strony, w rozpoznaniu powołania życiowego, z drugiej, w jego realizacji zgodnie z Ewangelią.

\section{Zakończenie}

Z podjętej refleksji wynika, że problematyka powołania do życia konsekrowanego jest uwzględniana $\mathrm{w}$ podstawie programowej i programach nauczania religii $\mathrm{W}$ szkołach ponadgimnazjalnych. Najwięcej uwagi poświęca się jej w ostatniej klasie, czyli w klasie trzeciej liceum, w czwartej klasie technikum i w drugiej klasie szkoły zawodowej. Należy to uznać za pozytywne zamierzenie, gdyż młodzież w tym okresie zastanawia się nad swoim życiem i wyborem dalszej drogi życiowej. Przed szkolną katechezą młodzieży szkół ponadgimnazjalnych stoi zatem zadanie ukazywania realizacji powołania do świętości nie tylko w małżeństwie, lecz także w życiu kapłańskim, zakonnym, misyjnym i konsekrowanym w świecie. Pozwoli to przezwyciężać młodzieży stereotypy w myśleniu o osobach konsekrowanych i tej formie życia. Dodatkowo, problematykę powołania do życia konsekrowanego należy wzbogacić o wdrażanie młodzieży do modlitwy o dobry wybór dalszej drogi życiowej.

W realizacji tematów o powołaniu do życia konsekrowanego pomocne są zarówno metody aktywizujące, jak i spotkania z zaproszonymi gośćmi (np. siostrami zakonnymi, kapłanami, świeckimi osobami konsekrowanymi), którzy świadczą swoim życiem o wartości życia radami ewangelicznymi. Dzięki takim spotkaniom młodzież jest zachęcana do stawiania pytań o osobiste powołanie, poszukiwania odpowiedzi i właściwego rozeznawania. Punktem odniesienia jest tu m.in. Ewangelia i nauczanie Kościoła. Pobudzając młodzież do refleksji i modlitwy, katecheta powinien sam modlić się za swoich uczniów oraz składać świadectwo wiary. Jest to ważne zarówno wtedy, gdy sam katecheta kroczy drogą rad

\footnotetext{
${ }^{47}$ Tamże.

${ }^{48}$ Tamże.

${ }^{49}$ PNR Liceum, s. 165; PNR Technikum, s. 202; Szkoła zawodowa, s. 220.
} 
ewangelicznych w życiu kapłańskim, zakonnym lub konsekrowanym w świecie, jak i wtedy gdy powołanie do świętości realizuje w małżeństwie lub w życiu samotnym. Niewątpliwie postawa katechety wzmacnia treści poruszane na katechezach poświęconych powołaniu do życia konsekrowanego.

Takie podejście warto wzbogacić o wykorzystanie różnych metod dyskusyjnych i problemowych połączonych $\mathrm{z}$ analizą tekstów biblijnych i katechizmowych poświęconych powołaniu do świętości w życiu oddanym Bogu i Jego Kościołowi ${ }^{50}$. Trzeba też wdrażać uczniów szkół ponadgimnazjalnych do modlitwy o dobre rozeznanie osobistego powołania. Również sam katecheta zobowiązany jest do modlitwy za swoich uczniów i ich dobre, zgodne z wolą Bożą, wybory życiowe.

\section{Bibliografia}

Franciszek: List apostolski Papieża Franciszka do zakonnic i zakonników na rozpoczęcie Roku Życia Konsekrowanego Świadkowie radości. (21 listopada 2014). http://w2.vatican.va/content/francesco/pl/apost letters/documents/papa-francesco letteraap 20141121_lettera-consacrati.html [dostęp: 15.09.2015].

Giemza B.: Apostolski wymiar życia konsekrowanego w nauczaniu Jana Pawła II : Studium teologicznopastoralne. Wrocław 2012.

Gołębiewski J.: Dar życia konsekrowanego. rozważania w świetle Adhortacji Vita consecrata Warszawa 1998.

Gurga A.: Komunikat na rozpoczęcie Roku Życia Konsekrowanego (16 listopada 2014). www.jasnagora.com/wydarzenie-8986 [dostęp: 11.09.2015].

Jan Paweł II: Posynodalna adhortacja apostolska o życiu konsekrowanym i jego misji w Kościele i w świecie Vita consecrata (25 maja 1996).

Komisja Wychowania Katolickiego Konferencji Episkopatu Polski: Świadek Chrystusa. Katecheza świadectwa wiary. Program nauczania religii dla liceum $\mathrm{nr}$ AZ-4-01/10. W: Komisja Wychowania Katolickiego Konferencji Episkopatu Polski: Program nauczania religii rzymskokatolickiej w przedszkolach i szkołach, Kraków 2010 s. 139-169.

Komisja Wychowania Katolickiego Konferencji Episkopatu Polski: Świadek Chrystusa. Katecheza świadectwa wiary. Program nauczania religii dla technikum nr AZ-6-01/10. W: Komisja Wychowania Katolickiego Konferencji Episkopatu Polski: Program nauczania religii rzymskokatolickiej w przedszkolach i szkołach. Kraków 2010 s. 171-206.

Komisja Wychowania Katolickiego Konferencji Episkopatu Polski: Świadek Chrystusa. Katecheza świadectwa wiary. Program nauczania religii dla szkoty zawodowej nr AZ-501/10. W: Komisja Wychowania Katolickiego Konferencji Episkopatu Polski: Program nauczania religii rzymskokatolickiej w przedszkolach i szkołach. Kraków 2010 s. 207-233.

Konferencja Episkopatu Polski: Podstawa programowa katechezy Kościoła katolickiego w Polsce. Kraków 2010.

\footnotetext{
${ }^{50}$ Tamże, s. 160. 198. 215-216.
} 
Mierzwa I.: Życie konsekrowane. W: Stownik teologiczny. Red. A. Zuberbier. Katowice 1998 s. 697-698.

Paszkowska T.: Konsekracja. W: Leksykon duchowości katolickiej. Red. M. Chmielewski. Lublin - Kraków 2002 s. 430-431.

Podlejski Z.: Życie konsekrowane w tajemnicy Kościoła. Kraków 2015.

Rakitina A.: Dlaczego współczesna młodzież nie spieszy się $z$ dorastaniem? http://pl.sputniknews.com/polish.ruvr.ru/2014_05 02/Dlaczego-wspolczesna-mlodzieznie-spieszy-sie-z-dorastaniem-4336/ [dostęp: 16.09.2015].

Sobór Watykański II: Dekret o przystosowanej do współczesności odnowie życia zakonnego Perfectae caritatis. W: Sobów Watykański II. Konstytucje. Dekrety. Deklaracje. Tłum. pl. Poznań 2002.

Sobór Watykański II: Konstytucja dogmatyczna o Kościele Lumen gentium. w: Sobór Watykański II: Konstytucje. Dekrety. Deklaracje. Tłum. pl. Poznań 2002.

Zubert B.:, Konsekrowane życie. W: Encyklopedia katolicka. T. 9. Red. A. Szostek, B. Migut, R. Sawa (i in.). Lublin 2002 kol. 677-678.

\section{ABSTRACT \\ The problem of vocation to the consecrated life in the catechesis of young people from secondary schools}

The vocation to the consecrated life occupies an important place among the various roads vocation. Contemporary culture marginalizes these issues. The young man guided in his life, above all what is fashionable, easy to reach, comfortable. He runs away from what a difficult, demanding asceticism, but valuable. In the catechesis of young people from secondary schools the issue of vocations to the consecrated life deserves special attention. The article describes the essence of the vocation to the consecrated life. Then, much attention was paid assumptions program teaching about the vocation to the consecrated life. Specific problems described in connection with the vocation to holiness. Attention was paid to the implementation of the youth to pray for a good understanding of the way personal vocation and testimony and prayer of catechist.

Key words: vocation, consecrated life, catechesis, young people.

Słowa kluczowe: powołanie, życie konsekrowane, katecheza, młodzież. 